\title{
ANALYSIS OF STUDENT DIFFICULTIES IN SOLVING TRIGONOMETRIC PROBLEM
}

\author{
Yusuf Faturohman ${ }^{1}$, Susan Amelia ${ }^{2}$ \\ ${ }^{1}$ IKIP Siliwangi, Jl. Jenderal Sudirman, Cimahi, Indonesia. \\ yusuffathurohman219@gmail.com \\ ${ }^{2}$ IKIP Siliwangi, Jl. Jenderal Sudirman, Cimahi, Indonesia. \\ susanamelia800@gmail.com
}

\begin{abstract}
This study is done to explore learning difficulties when students are given trig problems in solving math problems. Learning difficulties that encounter during learning and results in less than optimal learning. Trigonometric materials given are just about the number and ratio of sine cosine. Trigonometric materials are given based on the results of a study in student mathematics problem. The ability to solve mathematical problems based on 4 indicators is to understand problems, plan ideas to use, solve problems and reexamine them. This research was tested in praise of the sophomores science class 2 MAN Cimahi. This method of research with qualitative research with students analyzes answer results. The results of this research have found some difficulty with learning problem-solving skills. As for the fourth problem he gave, many of the students had difficulty solving the trigonometry problem.
\end{abstract}

\section{ARTICLE INFORMATION}

\begin{tabular}{|c|c|}
\hline Keywords & Article History \\
\hline Student difficulties & Submitted Feb 4, 2020 \\
\hline Trigonometric issues & Revised Apr 6, 2020 \\
\hline Problem solving skills & Accepted Apr 15, 2020 \\
\hline
\end{tabular}

Yusuf Faturohman

IKIP Siliwangi

J1. Jenderal Sudirman, Cimahi, Indonesia

Email: yusuffathurohman219@gmail.com

How to Cite

Faturohman, Y. \& Amelia, S., (2020). Analysis of Student Difficulties in Solving Trigonometric Problem. Kalamatika: Jurnal Pendidikan Matematika, 5(1), 1-8. 


\section{INTRODUCTION}

Math learning is a teaching process built by teachers to develop student problem solving and creativity that can enhance students' thinking ability, as well as that of improving the ability to construct new knowledge as a good mastery of mathematics (Susanto, 2013). It has a very important role. Math with a variety of roles makes it a very important science, and one of them is a thinking tool to get students to understand a mathematical concept that's being studied. What needs to be developed in math learning is 1) mastery of mathematical concepts; 2) problem-solving skills; 3) reasoning and communication skills; 4) the ability to think creatively and innovatively. Next, "education 2030 will ensure that all creativity is rooted in knowledge, developing creative and critical thinking and collaborative skills and building curiosity, courage, resilience." Then, the problems faced in math learning are increasingly complex and lead to the creative purposes of 21 st-century education. Thus, the ability to understand math and the need for creative thinking, so that it can be solved by math problems. Furthermore, learning has also been aimed at developing the potential of learners to have the ability to live as creative and innovative people with the ability to search, process, build, and use knowledge. That is how it needs to be mathematically creative thinking ability (Purba, Sinaga, Mukhtar, \& Surya, 2017).

According to mathematicians, it is the study of pattern and order. This indicates that a teacher must facilitate his students to learn to think through proper order (Shadiq, 2014). (Siswono, 2012) also notes some of the mathematical insights set out by experts from the 1940s through the 1970s. Mathematical notions are grouped into six categories: 1) mathematics as the science of Numbers and space, 2) mathematics as the science of quantity (quantity), 3) mathematics as the science of numbers, space, quantities, and vastness, 4) mathematics as the science of relationships, 5) math as the science of abstraction, and 6) mathematics as the science of deductive forms. This distinction is offset by the objects of mathematicians themselves. Also, math is the science of reasoning and related problems with Numbers (Fathani, 2009). One of the reasons why it should be taught is that it gives pleasure to the process of solving a challenging problem. One of the reasons why it should be taught is "to allow satisfaction to the process of solving a challenging problem" (Cockfort in Rosiyanti \& Widyasari, 2017). 
This research is to find out the extent of high school/MA students in solving trigonometric problems. Besides solving the problem according to (Polya, 2004) has 4 stages namely understanding the problem making plans to solve the problem, solving the problem, and checking again. Mathematical problems according to (Firdaus, 2017) are the rules in finding solutions that are not yet known by students, so finding mathematical solutions requires knowledge in the process of solving these problems. Problem-solving in this trigonometric material is very needed for students both the problems that occur in individuals, and in the environment around us. However, what happens in the field is different. Problemsolving in Indonesia is still not as expected. So that problem solving can be seen from the results of the achievement of Indonesian student learning achievements in the field of mathematics decreased on the international scene.

This problem solving is used in trigonometric problems which are implemented in class XI IPA 2 MAN Cimahi. This problem solving has a very important role in solving mathematical problem problems on trigonometry material in order to develop creative, systematic thinking skills and skills. According to NCTM (Firdaus, 2017) "problem-solving means engaging in a task for which the solution method is not known in advance. In order to find a solution, students must draw on their knowledge, and through the process, they will often develop new mathematical understandings. The sentence means that problem-solving means engaging in a task for which the solution to the method is not known beforehand. Solutions in mastering problem solving by solving mathematical problems that process the development of new understanding.

Trigonometry is a branch of mathematics that deals with triangular angles and trigonometric functions (Kariadinata, 2013). According to (Rusgianto, 2012), trigonometry is a relation of sine, cosine, tangent, cotangent, cosecant, secant, which has fulfilled certain preconditions. Meanwhile, according to the Big Indonesian Dictionary (KBBI), trigonometry is the science of measuring angles and borders with triangles (used in astronomy). Trigonometry is a branch of mathematics commonly used to measure length or angle accurately. Trigonometry also plays an important role in architecture, navigation, engineering and several branches of physics. 


\section{METHOD}

The research method is a technique or a way to find, obtain, conclude or record data, both in the form of primary data and secondary data used to compile a scientific work and then analyzing the factors related to the main issues so that there will be a truthful data obtained. This study uses descriptive-analytical research methods and verification analysis. Understanding the research method according to Sugiyono (2010) is as follows: "The research method is a scientific way to obtain data with specific purposes and uses." The research method that I use in this research is to use quantitative methods with a survey approach. According to Sugiyono (2010) states that: "Quantitative methods can be interpreted as positivistic methods because they are based on the philosophy of positivism. This method is a scientific method because it has fulfilled scientific principles that are concrete/empirical, objective, measurable, rational, and systematic. This method is also called the discovery method because this method discovered and developed a variety of new science and technology. Meanwhile, according to Sugiyono (2010), survey research is as follows: "Research conducted in large and small populations, but the data studied are data from samples taken from these populations, so that relative events, distribution, and relationships are found. -relationships between sociological and psychological variables". From the explanation, it can be concluded that research is a way to obtain, as well as record both primary and secondary data used to compile a scientific work which then analyzes the factors related to the problem so that truth is found on the data obtained. Survey approach used in data collection for example by distributing questionnaires.

The subjects of this study were students of class XI IPA 2 MAN Cimahi 35 academic year 2019/2020. The object studied by researchers is from the answers to the test and the results of interviews with students. The researcher took the class because according to the results of an interview with his teacher the class was good to be used as a research class. In this research, students work on trigonometry problems, after the research questions are done then collected to researchers and analyzed the trigonometry problems. The data that has been obtained is used to find out the extent of solving students' problems in trigonometry material. The process of solving through several stages, namely understanding the problem, planning problem solving, implementing plans, and looking back. The existence of this research is to obtain valid or desired data analysis results. 


\section{RESULT AND DISCUSSION}

Results of the analysis of students' difficulties in solving the mathematical problem of trigonometric material in class students XI IPA 2 in MAN Cimahi has the results of the analysis of the test answers and the results of interviews conducted on the research subject. Before the discussion of students ' learning difficulties, the students ' test answers were shown to analyze the extent to which students understood the problem and to know more broadly with the student's stage in answering trigonometric questions. Here are the students ' answers from each question like:

\section{Question 1}

Perhatikan gambar di samping! Hitunglah panjang $B C$ jika diketahui $h=12$ dan $\beta=30^{\circ}$.

Based on the results of student answers many students confuse to distinguish between where trigonometric comparisons and which ones include sine rules. From 35 students only 2 students who answer the problem correctly is to use the sine rules. Some do not use it with trigonometric comparisons. On that first problem, many of the students who did not write it are known and asked about the problem. So that the students do not understand the comparison of trigonometry and the students lack the concept of trigonometry given by researchers. Some students also have been able to answer correctly and answer wrong (as in Figure 1).
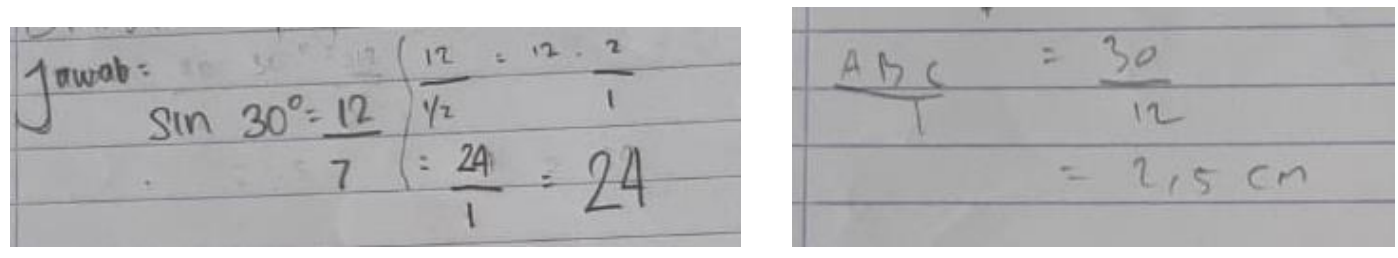

Figure 1. Example of student answers on question number 1

In question No. 2 using trigonometric comparisons of cosine, sine, and tangent

Question 2

Diketahui $\operatorname{Cos} A=\frac{4}{5}$, carilah nilai $x$, y dan $r$ jika perbandingan trigonometri tersebut berada di kuadran II!

Once the students have received their answers, some students understand the question of using trigonometric comparisons of cosine, sine, and tangent appropriately. However, some other students still do not understand the comparison, so that there are students can apply trigonometric comparisons (as in Figure 2). 

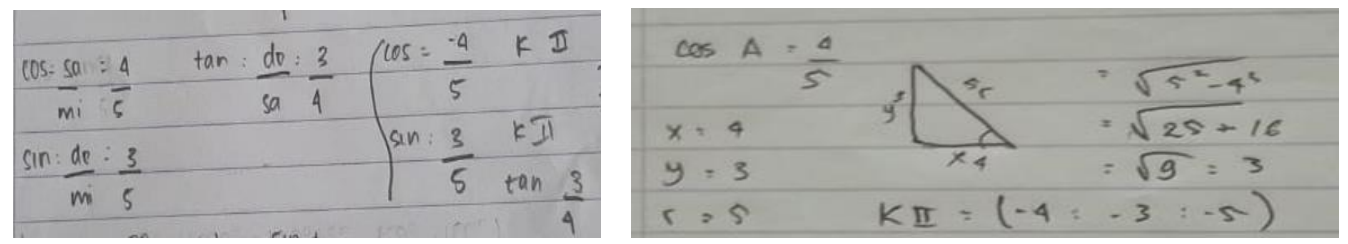

Figure 2. Example of student answers on question number 2

In question number 3 using trigonometric comparisons with related angles

\section{Question 3}

Carilah nilai dari: a. $\sin 120^{\circ}$ dan b.tan $300^{\circ}$ dengan menggunakan rumus perbandingan trigonometri sudut yang berelasi!

The results of students ' answers show that some students have been able to use a related trigonometric comparison of angles. But there are still those who have not appropriately answered in using a related angle comparison formula, selection of negative and positive signs in accordance with the equation (as in Figure 3).
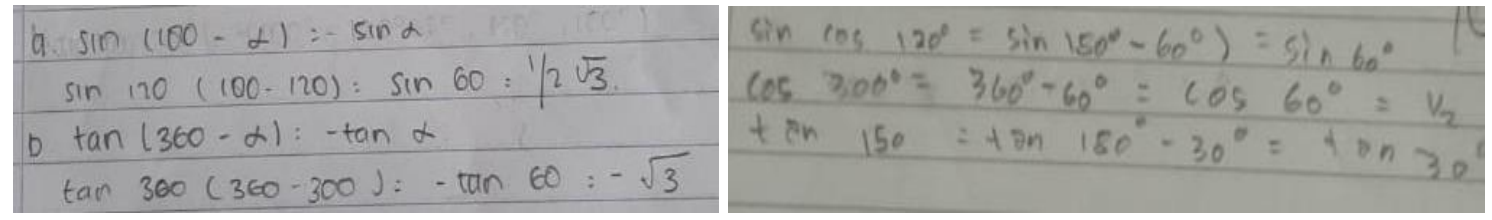

Figure 3. Example of student answers on question number 3

The objective of the problem given to measure the solving of mathematical problems in trigonometry is in Question No. 4 with the concept of converting cub coordinates to Cartesian and cartesian to polar coordinates

Question 4

Nyatakan koordinat kutub dari titik $(3,3 \sqrt{3})$ dan koordina kartesius dari titik $\left(9,120^{\circ}\right)$

The results of students' answers in figure 4 show that some students have been able to distinguish Cartesian coordinates and polar coordinates and change to the contrary. But others are still difficult in determining the value of $\mathrm{x}, \mathrm{Y}$. 

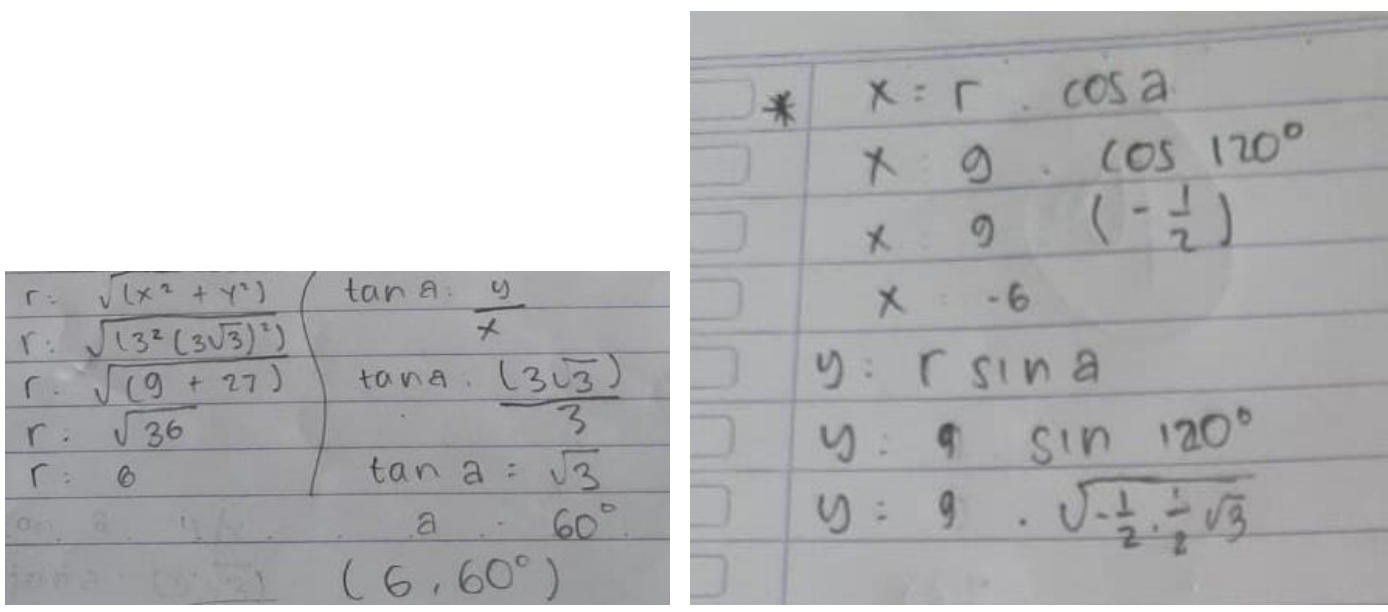

Figure 4. Example answer on question number 4

\section{CONCLUSION}

Based on the results of the analysis of mathematical learning barriers that have been conducted researchers get data analysis and discussion concluded as follow. In question No. 1 with sub-material trigonometric comparisons with the use of problem-solving obtained analysis barriers Learning Math is: a) students cannot distinguish between trigonometric comparisons with sine rule B) students have not yet Able to use trigonometric formulas with their formula. In question No. 2 with the sub-material trigonometric comparison with the cosine rules by using the problem-solving analysis barriers learned mathematical difficulties using positive and negative signs in the II quadrant. In question number 3 with sub material comparison of trigonometric angles related to using problem-solving analysis, barriers learn math difficult using a related angle comparison formula that leads to difficulty finding trigonometric value. In question No. 4 with sub material Cartesian coordinates and polar coordinates using troubleshooting analysis, barriers learn math difficult to determine the value of $\mathrm{x}, \mathrm{Y}, \mathrm{R}$ and angles of the already known points. In the results of data responses and interviews, students are known to problem-solving skills in trigonometric materials affecting the answers of students. Problem-solving skills tested on research conducted to make students better understand trigonometric comparisons with sine, cosine and tangent rules for students to be better at learning trigonometry.

Problem-solving process in trigonometric students who have a moderate understanding and 16 students who understand the problem well some other students do not understand the 
problem in answering trigonometric questions and have not been able to implement the resolution Problems to the fullest.

\section{REFERENCES}

Fathani, A. H. (2009). Matematika hakikat dan logika. Yogyakarta: Ar-Ruzz Media.

Firdaus, H. P. E. (2017). Analisis Kesalahan Mahasiswa dalam Menyelesaikan Masalah Matematika Berdasarkan Gaya Belajar.

Kariadinata, R. (2013). Trigonometri Dasar. Pustaka Setia.

Polya, G. (2004). How to Solve It: A New Aspect of Mathematical Method. Princeton University Press.

Purba, E. P., Sinaga, B., Mukhtar, M., \& Surya, E. (2017). Analysis of the Difficulties of the Mathematical Creative Thinking Process in the Application of Problem Based Learning Model. In 2nd Annual International Seminar on Transformative Education and Educational Leadership (AISTEEL 2017). Atlantis Press.

Rosiyanti, H., \& Widyasari, N. (2017). Pengembangan Buku Ajar Bar Modelling Berbasis Pemecahan Masalah pada Tema Berhemat Energi. FIBONACCI: Jurnal Pendidikan Matematika dan Matematika, 3(2), 111-120.

Rusgianto, M. . (2012). Trigonometri. Yogyakarta: CV. Grafika Indah.

Shadiq, F. (2014). Pembelajaran Matematika: Cara Meningkatkan Kemampuan Berpikir Siswa. Yogyakarta: Graha Ilmu.

Siswono, T. Y. E. (2012). Belajar dan Mengajar Matematika Anak Usia Dini. In Seminar Pendidikan Anak Usia Dini (pp. 1-9).

Sugiyono, P. (2010). Metode Penelitian Kuantitatif, Kualitatif, dan R\&D. Bandung: CV Alfabeta.

Susanto, A. (2013). Teori belajar dan pembelajaran di sekolah dasar. Jakarta: Kencana Prenada Media Group. 